\title{
Migraine is not the most common comorbidity in hidradenitis suppurativa patients
}

\section{Kluger, Nicolas}

2019-09

Kluger , N , Nuutinen, P , Lybeck, E , Ruohoalho , T T \& Salava , A 2019 , ' Migraine is not the most common comorbidity in hidradenitis suppurativa patients ' , Journal of the European Academy of Dermatology and Venereology, vol. 33 , no. 9 , pp. E330-E331. https://doi.org/10.1111/jdv.15625, https://doi.org/10.1111/jdv.15625, https://doi.org/10.1111/jdv.15625

http://hdl.handle.net/10138/312961

https://doi.org/10.1111/jdv.15625

acceptedVersion

Downloaded from Helda, University of Helsinki institutional repository.

This is an electronic reprint of the original article.

This reprint may differ from the original in pagination and typographic detail.

Please cite the original version. 
J Eur Acad Dermatol Venereol

Type: Letter to Editor

\section{Migraine is not the most common comorbidity in hidradenitis suppurativa patients}

Nicolas Kluger, MD, PhD; Pauliina Nuutinen, MD; Emilia Lybeck, MD; Timo Ruohoalho, MD; Alexander Salava, MD, PhD

Department of dermatology, allergology and venereology, Helsinki University Central Hospital, Helsinki, Finland

Key-words: comorbidities, epidemiology, hidradenitis suppurativa, migraine headache

Corresponding author: Nicolas Kluger

nicolas.kluger@hus.fi

Conflict of interest:

Dr. Nicolas Kluger has served as a consultant to AbbVie, and has received research funding from AbbVie and speaker fees from AbbVie (2015-2016)

Funding sources: none declared

This article has been accepted for publication and undergone full peer review but has not been through the copyediting, typesetting, pagination and proofreading process, which may lead to differences between this version and the Version of Record. Please cite this article as doi: $10.1111 /$ jdv. 15625

This article is protected by copyright. All rights reserved. 


\section{Editor,}

Migraine is the most common primary headache syndrome worldwide, affecting approximately $12 \%$ of the Caucasian population [1]. Migraine has been associated with various cardiovascular [2] and psychiatric co-morbidities [3], more recently inflammatory disorders such as psoriasis [4] and inflammatory bowel disease [5]. As hidradenitis suppurativa (HS) shares common comorbidity risks, we sought to investigate the possible link between migraine and HS. We explored the prevalence of migraine in patients that attended a tertiary care hospital (Department of dermatology, Helsinki University Hospital, Finland) and reviewed retrospectively all the attending patients with HS diagnosis between January and December 2018. Age, age at onset and at diagnosis, family history, smoking, comorbidities, Hurley stages and affected body sites were inquired in each patient. As the study was based on medical reports data with no direct patient contact, no ethical committee statement was required.

167 patients were included (97 women, mean age 38.4 years $+/-13.8$ ). The overall prevalence of patients with migraine in our cohort was $12.6 \%(n=21)$. Ten patients $(7.0 \%$ of the cohort, $47.6 \%$ of the patients with migraine) had a previously diagnosed migraine at the time of HS diagnosis. Table 1 summarizes patients' main characteristics. Briefly, HS patients with migraine were mainly women $(90.5 \%, p=0.001)$ with an onset of HS at an earlier age (17.0 vs. 27.4 years, Mann Whitney U-test, $p=0.001$ ). The patients were younger than without migraine (33.0 vs. 39.2 years) but without reaching significance. The prevalence was similar regarding family history, smoking history, body mass index, anatomical location of HS and Hurley stages. Among comorbidities, there was no difference regarding acne, cardiovascular (hypertension, arrhythmia, lower limb arteriopathy, stroke, gout) and pulmonary disorders (asthma, chronic bronchitis, sleep apnea), dyslipidemia, diabetes, hypothyroidism, or psychiatric disorders, except for bipolar disorder $(p=0.001)$. Patients with migraine were more likely to have psoriasis ( $p=0.04)$, inflammatory joint disease $(p=0.002)$, mainly spondyloarthropathies $(p=0.005)$. Multivariate logistic regression (taking into account gender, age, smoking, psoriasis, hypertension, inflammatory joint disease and psychiatric disorders) showed that female gender (OR 9.8 [1.5-63.1], $p=0.016$ ), psoriasis (OR 17.2 [2.2136.3], $p=0.007)$, psychiatric disorders (OR 3.7 [1.1-11.8], $p=0.028$ ) and inflammatory joint 
diseases (OR 6.9 [1.2-38.4], $p=0.027$ ) were associated with migraine among patients with HS.

A comprehensive literature search could not reveal previous reports about the possible association of migraine and HS. The pathophysiology of migraine involves changes in different parts of the central and peripheral nervous system, and complex molecular mechanisms (e.g. release of calcitonin gene-related peptides) $[6,7]$. Triggers include behavioral factors such as diet, stress, sleep disturbances as well as medicaments $[6,7]$. Patients with HS may share these triggering factors $[8,9]$. In our patient cohort, migraine prevalence was similar to the general population [1], but we did not perform a direct comparison with the general population. Apart from the earlier onset of HS in patients with migraine, we found that patients with migraine were more likely to have other comorbidities that have been previously reported. Main limitations of the study include a relatively small cohort size, the absence of a control group, a single tertiary center and the fact that the subtypes of migraine were not discriminated. Our results suggest that migraine is associated indirectly with other inflammatory comorbidities of HS than per se. Larger studies need to confirm these results.

\section{References}

1. Younger DS. Epidemiology of Migraine. Neurol Clin. 2016;34:849-861.

2. Mahmoud AN, Mentias A, Elgendy AY, Qazi A, Barakat AF, Saad M, Mohsen A, Abuzaid A, Mansoor H, Mojadidi MK, Elgendy IY. Migraine and the risk of cardiovascular and cerebrovascular events: a meta-analysis of 16 cohort studies including 1152407 subjects. BMJ Open. 2018;8:e020498.

3. Patel RS, Virani S, Saeed H, Nimmagadda S, Talukdar J, Youssef NA. Gender Differences and Comorbidities in U.S. Adults with Bipolar Disorder. Brain Sci. 2018;8(9).

4. Egeberg A, Mallbris L, Hilmar Gislason G, Skov L, Riis Hansen P. Increased risk of migraine in patients with psoriasis: A Danish nationwide cohort study. J Am Acad Dermatol. 2015;73:829-835.

This article is protected by copyright. All rights reserved. 
5. Moisset X, Bommelaer G, Boube M, Ouchchane L, Goutte M, Dapoigny M, Dallel R, Guttmann A, Clavelou P, Buisson A. Migraine prevalence in inflammatory bowel disease patients: A tertiary-care centre cross-sectional study. Eur J Pain. 2017;21:1550-1560.

6. Charles A. The pathophysiology of migraine: implications for clinical management. Lancet Neurol. 2018;17(2):174-182.

7. Puledda F, Messina R, Goadsby PJ. An update on migraine: current understanding and future directions. J Neurol. 2017 Sep;264(9):2031-2039.

8. Garg A, Papagermanos V, Midura M, Strunk A, Merson J. Opioid, alcohol, and cannabis misuse among patients with hidradenitis suppurativa: A population-based analysis in the United States. J Am Acad Dermatol. 2018;79(3):495-500.e1.

9. Huilaja L, Tiri H, Jokelainen J, Timonen M, Tasanen K. Patients with Hidradenitis Suppurativa Have a High Psychiatric Disease Burden: A Finnish Nationwide Registry Study. J Invest Dermatol. 2018;138(1):46-51.

This article is protected by copyright. All rights reserved. 
Table 1. Characteristics of HS patients with and without migraine

\begin{tabular}{|c|c|c|c|}
\hline & $\begin{array}{l}\text { Migraine } \\
n(\%)\end{array}$ & $\begin{array}{l}\text { No migraine } \\
n(\%)\end{array}$ & $\begin{array}{l}\mathrm{P}<0.05 \\
\text { Chi2 } \\
\text { or Mann-Whitney U }\end{array}$ \\
\hline Total (N) & 21 & 146 & \\
\hline \multicolumn{4}{|l|}{ Gender } \\
\hline $\begin{array}{l}\text { Men (\%) } \\
\text { Women (\%) }\end{array}$ & $\begin{array}{l}2(9.5) \\
19(90.5)\end{array}$ & $\begin{array}{l}68(46.6) \\
78(53.4)\end{array}$ & 0.001 \\
\hline Mean age (years, SD) & $33.0(11.3)$ & $39.2(14.0)$ & NS \\
\hline $\begin{array}{l}\text { Mean age at diagnosis } \\
\text { (years, SD) }\end{array}$ & $28.4(12.9)$ & $34.9(12.8)$ & NS \\
\hline $\begin{array}{l}\text { Mean age at first } \\
\text { symptoms (years, SD) }\end{array}$ & $17.0(7.8)$ & $27.4(11.8)$ & 0.001 \\
\hline Familial History of HS* & $2 / 7(28.6)$ & $24 / 56(42.8)$ & NS \\
\hline \multicolumn{4}{|l|}{ Hurley** } \\
\hline Hurley I & $7(63.6)$ & $27(37.5)$ & NS \\
\hline Hurley II & $3(27.3)$ & $30(41.6)$ & \\
\hline Hurley III & $1(9.1)$ & $15(20.8)$ & \\
\hline \multicolumn{4}{|l|}{ Smoking history } \\
\hline Ever smokers & $13 / 20(65)$ & $105 / 138(76.1)$ & NS \\
\hline Active smokers & $10(50)$ & $72(52.1)$ & NS \\
\hline BMI mean (SD) & $33.5(5.9)$ & $32.3(8.1)$ & NS \\
\hline \multicolumn{4}{|l|}{ Comorbidities } \\
\hline \multicolumn{4}{|l|}{ Weight } \\
\hline Overweight and obesity & $18(85.7)$ & $103(70.5)$ & NS \\
\hline Obesity & $13(61.9)$ & $72(49.3)$ & NS \\
\hline Hypertension & $1(4.8)$ & $36(24.6)$ & 0.04 \\
\hline Dyslipidemia & $2(9.5)$ & $16(10.9)$ & NS \\
\hline Thyroid disease & $3(14.3)$ & $15(10.3)$ & NS \\
\hline Diabetes type 2 & $1(4.8)$ & $25(17.2)$ & NS \\
\hline Asthma & $4(19.0)$ & $20(13.7)$ & NS \\
\hline
\end{tabular}

This article is protected by copyright. All rights reserved. 


\begin{tabular}{|c|c|c|c|}
\hline Acne & $5(23.8)$ & $41(28.1)$ & NS \\
\hline \multicolumn{4}{|l|}{$\begin{array}{l}\text { Autoimmune and } \\
\text { inflammatory disorders }\end{array}$} \\
\hline Psoriasis & $4(19.0)$ & $9(6.2)$ & 0.04 \\
\hline $\begin{array}{l}\text { Inflammatory bowel } \\
\text { disease (total)*** }\end{array}$ & $1(4.8)$ & $6(4.1)$ & NS \\
\hline $\begin{array}{l}\text { Inflammatory joint } \\
\text { disease (total)**** }\end{array}$ & $5(23.8)$ & $7(4.8)$ & 0.002 \\
\hline Spondyloarthropathy & $3(14.3)$ & $3(2.0)$ & 0.005 \\
\hline $\begin{array}{l}\text { Psychiatric } \\
\text { diseases } * * * *\end{array}$ & $12(57.4)$ & 48 (32.9) & 0.03 \\
\hline Anxiety & $4(19.0)$ & $24(16.4)$ & NS \\
\hline Depression & $6(28.6)$ & $33(22.6)$ & NS \\
\hline Bipolar disorder & $4(19.0)$ & $4(2.7)$ & 0.001 \\
\hline \multicolumn{4}{|c|}{ NS: Not significant; SD: Standard Deviation } \\
\hline \multicolumn{4}{|c|}{$\begin{array}{l}\text { *Family history could be obtained in } 63 \text { patients } \\
* * 11 \text { vs. } 77 \text { patients } \\
* * * \text { Includes Crohn's disease and ulcerative colitis } \\
* * * * \text { Includes reactive, rheumatoid, psoriatic arthritis and spondyloarthropathy } \\
* * * * * \text { Includes also schizophrenia, hyperactivity, binge eating disorder, anorexia, post-traumatic } \\
\text { stress disorder, compulsive disorder. Several diagnoses can apply to a patient. }\end{array}$} \\
\hline
\end{tabular}

This article is protected by copyright. All rights reserved. 